\title{
A STUDY ON READER'S PREFERENCE OF THE HINDU AND THE NEW INDIAN EXPRESS NEWSPAPERS
}

\author{
K. Rajini*
}

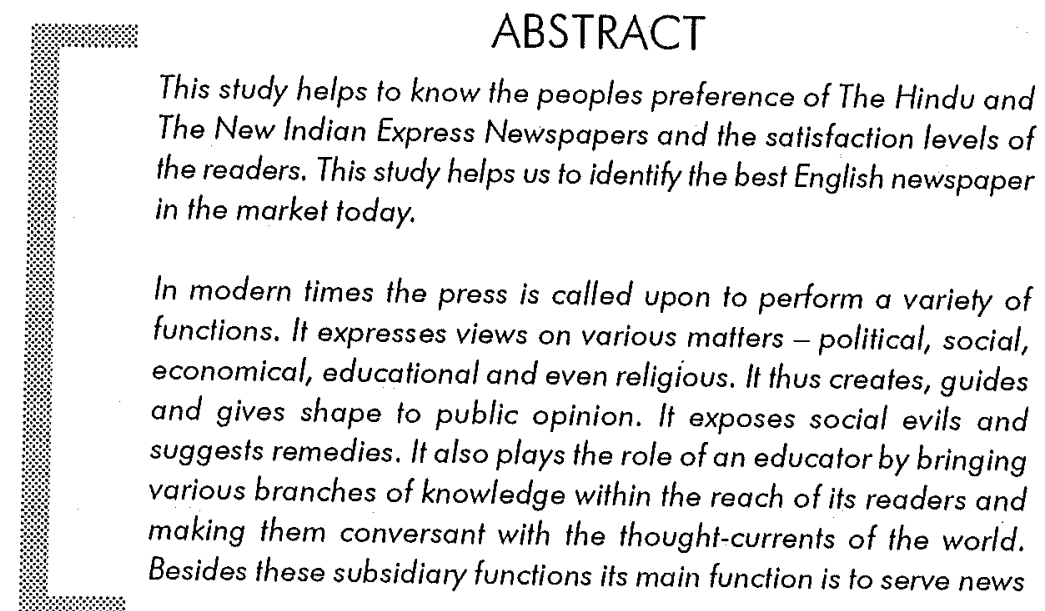

* Lecturer (S.G), Dept. of Business Management, Sri Vasavi College, Erode - 638316. Mobile No. 9842025013 
of all descriptions with a view to making us familiar with what is happening in the world.

THE HINDU newspaper is the best when compared to THE NEW INDIAN EXPRESS newspaper due to various factors such as best photo clipping, editorial essays, good advertising, news approach of an event, correct employment news and etc.

\section{Introduction}

In the present world, newspapers have become as necessary as food and clothing. This is especially true in the case of modern educated people who cannot enjoy their breakfast unless they have mornings newspaper. Multifarious events are taking place around the world and they are reported everywhere by newspapers. Without the help of newspapers we cannot know the latest developments that are taking place around us.

The word "press" means newspaper (or) periodicals. It also means the people associated with newspapers, such as editors, reporters, publishers etc. Newspapers play a very vital role in nation building, bringing revolutions, exposing crimes and criminals and educating the masses. It is rightly said that pen is mightier than sword. Thus the press is an effective medium of public information.

The people of India became familiar with the press when the first Indian newspaper "Calcutta Gazette" was launched in 1784. At the heels of 'Calcutta Gazette' came 'Madras Courier' in 1785. The 'Bombay Herald' was launched in 1789. The English journalism in India is much older than the regional language journalism. The 'Times of India' published from Mumbai is the oldest existing daily in English. In regional languages 'Bombay Samachar' and 'Gujarat daily' both in Gujarathi language are the oldest existing regional language dailies.

\section{Scope of the study}

Due to the necessity of knowing the local, national, international news, people have to depend on newspaper. However people are now aware of many newspapers available in the market. 
This study helps to know the people's preference of The Hindu and the New Indian Express Newspapers and the satisfaction levels of the readers.

This study helps us to identify the best English newspaper in the market today.

\section{Research Methodology}

A research design is purely and simply basic framework (or) plan for a study that guide the collection of data analysis of the data. In consumer surveys, the descriptive research design in collection and analysis of the data were adopted.

\section{Research Design}

Research design is the map (or) blueprint according to which the research is to be conducted. The research design call for decisions on the data sources, research approaches, research instruments, sampling plan and contact methods.

\section{a) Data Sources}

The researchers collected the primary data through survey research by the use of questionnaires.

Secondary data was collected from the firm's internal records journal, newspapers and other published documents.

\section{b) Research Instruments}

The researchers used close-ended questions in the form of questionnaire to collect the primary data.

\section{Sampling Design}

In this study the researcher have adopted non-probability random sample technique for their survey. So, convenient sampling has been used. 


\section{Sampling Plan}

i) Sample Unit

The sample unit of the research is that of population, that is respondents who reads both The Hindu and The New Indian Express regularly.

ii) Sample Size

The sample size is 100 readers who regularly read The Hindu and The New Indian Express Newspapers.

\section{Period Covered by the Study}

The study covers a period of 4 months which was utilized for collecting the primary data, analysis of data and preparing the final report.

\section{Objectives of the Study}

1. To study the preference of readers towards particular newspaper.

2. To analyse the various sources that influences the readers to purchase that newspaper.

3. To study the changes required in the newspaper by the reader in future.

\section{Limitations of the Study}

1) The data given by the readers are limited to readers own perception, opinion, emotion, knowledge, feelings and awareness.

2) The result of the study is fully dependent on the correctness of the information given by the respondents through questionnaire.

3) The data collected for the study are quantitative being subject to personal bias of the readers.

4) The sample size is just 100 which are very small for generalizations.

\section{Review of Literature}

A review of literature is supposed to shed light into the study on both "The Hindu" and "The New Indian Express" Newspapers. Hence the research. 
Murali Mantrala and Esther Thorson (2007) recently examined the profitability of newspaper. They collaborated with marketing doctoral students Hari Sridhar and Prasad Naik who is now professor at the University of California - Davis. The team of researchers focused on three areas of operation news quality, distribution and circulation and advertising - by analyzing financial data of small to medium sized newspapers with circulations of 85000 or less. Research revealed that news quality most directly affects the bottom line.

Evin (2006) analyse the findings of a new study that examined the top 50 Italian newspapers compared the results of the 25 most circulated papers in the US with the top 25 Italian papers and results are pretty interesting and show that even the least circulated papers are offering most web tools on their skies.

\section{Data Analysis and Interpretation}

\section{Percentage Analysis}

Table 1: Age of the Respondents

\begin{tabular}{|c|c|c|c|}
\hline Sl. No. & Age & No. of Respondents & Percentage \\
\hline 1. & $20-30$ yrs. & 56 & 56.0 \\
2. & $31-40$ yrs. & 24 & 24.0 \\
3. & $41-49$ yrs. & 16 & 16.0 \\
4. & $50 \&$ above & 4 & 4.0 \\
\hline & Total & 100 & 100.0 \\
\hline
\end{tabular}

Among 100 respondents $56 \%$ of the respondents belong to $20-30$ years of age, $24 \%$ of the respondents belong to $31-40$ years of age, $16 \%$ of the respondents belong to $41-49$ years of age and $4 \%$ of the respondents belong to above 50 years of age.

Hence majority of the respondents in our study belong to $20-30$ years of age. 
Table 2: Gender of the Respondents

\begin{tabular}{|c|c|c|c|}
\hline SI. No. & Gender & No. of Respondents & Percentage \\
\hline 1. & Male & 69 & 69.0 \\
2. & Female & 31 & 31.0 \\
\hline & Total & 100 & 100.0 \\
\hline
\end{tabular}

Among 100 respondents $69 \%$ of the respondents belong to male category and $31 \%$ of the respondents belong to female category.

Hence majority of the respondents belong to male category.

Table 3: Occupation of the Respondents

\begin{tabular}{|c|l|c|c|}
\hline SI. No. & Occupation & No. of Respondents & Percentage \\
\hline 1. & Professional & 25 & 25.0 \\
2. & Students & 27 & 27.0 \\
3. & Business & 24 & 24.0 \\
4. & Employee & 24 & 24.0 \\
\hline & Total & 100 & 100.0 \\
\hline
\end{tabular}

It is observed from the above table that $25 \%$ of the respondents belong to professional category, $27 \%$ of the respondents belong to students category, $24 \%$ of the respondents belong to business category and remaining $24 \%$ of the respondents constitute employee category.

Thus it can be concluded that majority of the respondents belong to student category.

Table 4: Educational qualification of the respondents

\begin{tabular}{|c|l|c|c|}
\hline SI. No. & Educational qualification & No. of Respondents & Percentage \\
\hline 1. & School Level & 10 & 10.0 \\
2. & UG level & 54 & 54.0 \\
3. & PG level & 27 & 27.0 \\
4. & Others & 9 & 9.0 \\
\hline & Total & 100 & 100.0 \\
\hline
\end{tabular}


The above table shows that the $10 \%$ of the respondents are educated at school level, $54 \%$ of the respondents at UG level, $27 \%$ of the respondents at PG level and $9 \%$ of the respondents include above PG level ie M.Phil., Ph.D etc.,

Hence the majority of $54 \%$ of the respondents have had UG level education.

Table 5: Simple Usage of language

\begin{tabular}{|c|l|c|c|}
\hline Sl. No. & \multicolumn{1}{|c|}{ Opinion } & No. of Respondents & Percentage \\
\hline 1. & The Hindu & 42 & 42 \\
2. & The New Indian Express & 58 & 58 \\
\hline & Total & 100 & 100.0 \\
\hline
\end{tabular}

The above table shows out of the total of 100 respondents $42 \%$ of the respondents have chosen The Hindu for simple usage of language, remaining $58 \%$ of the respondents have chosen The New Indian Express for the same.

From the above table it can be concluded that The New Indian Express Newspaper has a simple usage of language.

Table 6: New Approach of Event

\begin{tabular}{|c|l|c|c|}
\hline Sl. No. & \multicolumn{1}{|c|}{ Opinion } & No. of Respondents & Percentage \\
\hline 1. & The Hindu & 58 & 58.0 \\
2. & The New Indian Express & 42 & 42.08 \\
\hline & Total & 100 & 100.0 \\
\hline
\end{tabular}

The above table shows that in total of 100 respondents $58 \%$ of the respondents have chosen The Hindu for new approach of event, remaining $42 \%$ of the respondents have chosen The New Indian Express for the same.

Hence it can be concluded that The Hindu newspaper has a different way of presentation of events. 
Table 7: Editorial matured essays

\begin{tabular}{|c|l|c|c|}
\hline SI. No. & \multicolumn{1}{|c|}{ Opinion } & No. of Respondents & Percentage \\
\hline 1. & The Hindu & 51 & 51.0 \\
2. & The New Indian Express & 49 & 49.0 \\
\hline & Total & 100 & 100.0 \\
\hline
\end{tabular}

The above table shows that out of the total of 100 respondents, $51 \%$ of the respondents, have chosen The Hindu for matured essays, remaining $49 \%$ of the respondents have chosen The New Indian Express for matured essays.

From the above table we can conclude that The Hindu contains matured essays in the editorial column.

Table 8: Welfare Programs of Government

\begin{tabular}{|c|l|c|c|}
\hline SI. No. & \multicolumn{1}{|c|}{ Opinion } & No. of Respondents & Percentage \\
\hline 1. & The Hindu & 56 & 56.0 \\
2. & The New Indian Express & 44 & 44.0 \\
\hline & Total & 100 & 100.0 \\
\hline
\end{tabular}

The above table shows that in the total of 100 respondents $56 \%$ of the respondents choose 'The Hindu' for publishing many welfare programs of government, remaining $44 \%$ of the respondents have chosen The New Indian Express for the same.

From the above table we can conclude that the respondents feel that "The Hindu" published lot of welfare programs announced by the government.

Table 9: Paper Providing Correct Employment News

\begin{tabular}{|c|l|c|c|}
\hline SI. No. & \multicolumn{1}{|c|}{ Opinion } & No. of Respondents & Percentage \\
\hline 1. & The Hindu & 56 & 56.0 \\
2. & The New Indian Express & 44 & 44.0 \\
\hline & Total & 100 & 100.0 \\
\hline
\end{tabular}


The above table shows that in the total of 100 respondents $56 \%$ of the respondents have chosen "The Hindu" for providing correct employment news, remaining $44 \%$ of the respondents have chosen 'The New Indian Express' for the same.

Hence we can conclude that the majority of $56 \%$ of the respondents feel that "The Hindu" newspaper provides authenticated employment news.

Table 10: International News Accurate

\begin{tabular}{|c|l|c|c|}
\hline SI. No. & \multicolumn{1}{|c|}{ Opinion } & No. of Respondents & Percentage \\
\hline 1. & The Hindu & 55 & 55.0 \\
2. & The New Indian Express & 45 & 45.0 \\
\hline & Total & 100 & 100.0 \\
\hline
\end{tabular}

The above table shows that in the total of 100 respondents $55 \%$ of the respondents have chosen 'The Hindu' for newspaper providing international news accurately, remaining $45 \%$ of the respondents have chosen The New Indian express for the same.

Hence we can conclude that 'The Hindu' newspaper provides accurate international news.

Table 11: Paper Gives Enough of Educational News

\begin{tabular}{|c|l|c|c|}
\hline Sl. No. & \multicolumn{1}{|c|}{ Opinion } & No. of Respondents & Percentage \\
\hline 1. & The Hindu & 49 & 49.0 \\
2. & The New Indian Express & 51 & 51.0 \\
\hline & Total & 100 & 100.0 \\
\hline
\end{tabular}

The above table shows that in the total of 100 respondents $49 \%$ of the respondents have chosen 'The Hindu' for providing more educational news, remaining $51 \%$ of the respondents have chosen 'The New Indian Express' for the same.

Hence we can conclude that "The New Indian Express" newspaper provides sufficient educational news. 
Table 12: Provides Up-to-date Sports News

\begin{tabular}{|c|l|c|c|}
\hline SI. No. & \multicolumn{1}{|c|}{ Opinion } & No. of Respondents & Percentage \\
\hline 1. & The Hindu & 44 & 44.0 \\
2. & The New Indian Express & 56 & 56.0 \\
\hline & Total & 100 & 100.0 \\
\hline
\end{tabular}

The above table shows that in the total of 100 respondents $44 \%$ of the respondents have chosen 'The Hindu' for providing up-to-date sports news, remaining $56 \%$ of the respondents have chosen 'The New Indian Express' for the same.

Hence we can conclude from the above table that "The New Indian Express" newspaper provides up-to-date sports news.

Table 13: Merits and Demerits of Rüling Government

\begin{tabular}{|c|l|c|c|}
\hline SI. No. & Opinion & No. of Respondents & Percentage \\
\hline I. & The Hindu & 57 & 57.0 \\
2. & The New Indian Express & 43 & 43.0 \\
\hline & Total & 100 & 100.0 \\
\hline
\end{tabular}

The above table shows that in the total of 100 respondents $57 \%$ of the respondents have chosen 'The Hindu' for providing both merits and demerits of the government, remaining $43 \%$ of the respondents have chosen 'The New Indian Express' for the same.

Hence, from the above table we can conclude that majority $57 \%$ of the respondents felt that "The Hindu" Newspaper provides the merits as well as demerits of the government.

Table 14: Information for Youth Development

\begin{tabular}{|c|l|c|c|}
\hline SI. No. & \multicolumn{1}{|c|}{ Opinion } & No. of Respondents & Percentage \\
\hline 1. & The Hindu & 47 & 47.0 \\
2. & The New Indian Express & 53 & 53.0 \\
\hline & Total & 100 & 100.0 \\
\hline
\end{tabular}


The above table shows that in the total of 100 respondents $47 \%$ of the respondents have chosen The Hindu newspaper for providing more information for youth development, remaining $53 \%$ of the respondents have chosen The New Indian Express for the same.

Hence we can conclude that 'The New Indian Express' provides more information for youth development.

Table 15: Interview of Achieved Person

\begin{tabular}{|c|l|c|c|}
\hline SI. No. & \multicolumn{1}{|c|}{ Opinion } & No. of Respondents & Percentage \\
\hline 1. & The Hindu & 58 & 58.0 \\
2. & The New Indian Express & 42 & 42.0 \\
\hline & Total & 100 & 100.0 \\
\hline
\end{tabular}

The above table shows that in the total of 100 respondents $58 \%$ of the respondents have chosen 'The Hindu' newspaper for interview of achieved person, remaining $42 \%$ of the respondents have chosen 'The New India Express' for the same.

From the above study we can conclude that 'The Hindu' has the majority of providing the interview of achieved person.

Table 16: Business and Economy

\begin{tabular}{|c|l|c|c|}
\hline Sl. No. & Opinion & No. of Respondents & Percentage \\
\hline 1. & The Hindu & 55 & 55.0 \\
2. & The New Indian Express & 45 & 45.0 \\
\hline & Total & 100 & 100.0 \\
\hline
\end{tabular}

The above table shows that in the total of 100 respondents $55 \%$ of the respondents have chosen 'The Hindu' for business and economy, remaining $45 \%$ of the respondents have chosen The Indian Express for the same.

From that study we get in to conclusion that 'The Hindu' gives the authenticated business and economy news. 
Table 17: Maximum Government Contracts / Tenders

\begin{tabular}{|c|l|c|c|}
\hline SI. No. & \multicolumn{1}{|c|}{ Opinion } & No. of Respondents & Percentage \\
\hline 1. & The Hindu & 56 & 56.0 \\
2. & The New Indian Express & 44 & 44.0 \\
\hline & Total & 100 & 100.0 \\
\hline
\end{tabular}

The above table shows that in the total of 100 respondents $56 \%$ of the respondents have chosen 'The Hindu' for maximum Government contracts/ Tenders, remaining $44 \%$ of the respondents have chosen 'The New Indian Express' for the same.

It is concluded from the above study that 'The Hindu' has the maximum - Government contracts / Tenders news.

Table 18: More Information Relating to Stock Market

\begin{tabular}{|c|l|c|c|}
\hline SI. No. & \multicolumn{1}{|c|}{ Opinion } & No. of Respondents & Percentage \\
\hline 1. & The Hindu & 59 & 59.0 \\
2. & The New Indian Express & 41 & 41.0 \\
\hline & Total & 100 & 100.0 \\
\hline
\end{tabular}

The above table shows that in the total of 100 respondents $59 \%$ of the respondents have chosen 'The Hindu' for stock market information, remaining $41 \%$ of the respondents have chosen 'The New Indian Express' for the same. Hence, from that we can finally conclude that 'The Hindu' gives updated news of stock market.

Table 19: Concentrated more on Advertisements

\begin{tabular}{|c|l|c|c|}
\hline SI. No. & \multicolumn{1}{|c|}{ Opinion } & No. of Respondents & Percentage \\
\hline 1. & The Hindu & 63 & 63.0 \\
2. & The New Indian Express & 37 & 37.0 \\
\hline & Total & 100 & 100.0 \\
\hline
\end{tabular}

The above table shows that in the total of 100 respondents $63 \%$ of the respondents have chosen 'The Hindu' for advertisement news, remaining 
$37 \%$ of the respondents have chosen 'The New Indian Express' for the same.

From that we can conclude that 'The Hindu' concentrates more on advertisements.

Table 20: More Information about Currency Value

\begin{tabular}{|c|l|c|c|}
\hline SI. No. & \multicolumn{1}{|c|}{ Opinion } & No. of Respondents & Percentage \\
\hline 1. & The Hindu & 49 & 49.0 \\
2. & The New Indian Express & 51 & 51.0 \\
\hline & Total & 100 & 100.0 \\
\hline
\end{tabular}

The above table shows that in the total of 100 respondents $51 \%$ of the respondents have chosen 'The New Indian express' for currency value information, remaining $49 \%$ of the respondents have chosen 'The Hindu' for the same.

From the above study we can conclude that 'The New Indian Express' has the majority in providing the currency value news.

Table 21: Letter to the Editor

\begin{tabular}{|c|l|c|c|}
\hline SI. No. & \multicolumn{1}{|c|}{ Opinion } & No. of Respondents & Percentage \\
\hline 1. & The Hindu & 54 & 54.0 \\
2. & The New Indian Express & 46 & 46.0 \\
\hline & Total & 100 & 100.0 \\
\hline
\end{tabular}

The above table shows that in the total of 100 respondents $54 \%$ of the respondents have chosen 'The Hindu' for best letter to the editor, remaining $46 \%$ of the respondents have chosen 'The New Indian Express' for the same.

From that we get into conclusion that 'The Hindu' readers prefer letters to the Editor column the most. 
Table 22: Photo Clippings

\begin{tabular}{|c|l|c|c|}
\hline SI. No. & Opinion & No. of Respondents & Percentage \\
\hline 1. & The Hindu & 54 & 54.0 \\
2. & The New Indian Express & 46 & 46.0 \\
\hline & Total & 100 & 100.0 \\
\hline
\end{tabular}

The above table shows that in the total of 100 respondents $54 \%$ of the respondents have chosen 'The Hindu' for photo clippings remaining $46 \%$ of the respondents chosen 'The New Indian Express' for the same.

Hence from that we can conclude that the photo clippings of 'The Hindu' has been preferred the most.

Table 23: Paper Give Useful Supplements

\begin{tabular}{|c|l|c|c|}
\hline SI. No. & Opinion & No. of Respondents & Percentage \\
\hline 1. & The Hindu & 58 & 58.0 \\
2. & The New Indian Express & 42 & 42.0 \\
\hline & Total & 100 & 100.0 \\
\hline
\end{tabular}

The above table shows that in the total of 100 respondents $58 \%$ of the respondents chose 'The Hindu' for best supplements, remaining $42 \%$ of the respondents have chosen 'The New Indian Express' for the same.

From the above study we can conclude that 'The Hindu' has the majority in giving useful and best supplements.

\section{Chi-square Analysis}

Table 24: Age and Opinion about the Editorial Essays (Two-way Table)

\begin{tabular}{|c|l|c|c|c|}
\hline SI. No. & \multirow{2}{*}{ Age } & \multicolumn{2}{|c|}{ Opinion about the editorial essays } & \multirow{2}{*}{ Total } \\
\cline { 3 - 4 } & & The Hindu & The New Indian Express & \\
\hline 1 & $20-30$ yrs. & 31 & 25 & 56 \\
2 & $31-40$ yrs. & 9 & 15 & 24 \\
3 & $41-49$ yrs. & 11 & 5 & 16 \\
4 & Above 49 yrs. & 0 & 4 & 4 \\
\hline & Total & 51 & 49 & 100 \\
\hline
\end{tabular}


Null Hypothesis $\left(H_{0}\right)$

Alternative Hypothesis $\left(H_{1}\right)$ - There is close significant relationship between age and opinion about the editorial essays.

\section{Chi-square $\left(\chi^{2}\right)$ Calculation:}

Calculated $\chi^{2}$ value

Degree of freedom

Table value

Significant result
$=8.356$

$=3$

$=7.815$

$=\quad$ Significant at $5 \%$ level

\section{Inference}

It is found from the above analysis that calculated chi-square value is greater than the table value at 3 degree of freedom. So, we conclude that, there is close significant relationship between the age and opinion about the editorial essays.

Table 25: Age and Opinion about the Advertisement

(Two-way Table)

\begin{tabular}{|c|c|c|c|c|}
\hline SI. No. & Age & \multicolumn{2}{|c|}{ Opinion about advertisement } & Total \\
\cline { 3 - 4 } & & The Hindu & The New Indian Express & \\
\hline 1 & $20-30$ yrs. & 40 & 16 & 56 \\
2 & $31-40$ yrs. & 15 & 9 & 24 \\
3 & $41-49$ yrs. & 8 & 8 & 16 \\
4 & Above 49 yrs. & 0 & 4 & 4 \\
\hline & Total & 63 & 37 & 100 \\
\hline
\end{tabular}

Null Hypothesis $\left(H_{0}\right)$

- There is no significant relationship between age and opinion about the advertisement.

Alternative Hypothesis $\left(H_{1}\right)$ - There is close significant relationship between age and opinion about the advertisement. 


\section{Chi-square $\left(\chi^{2}\right)$ Calculation:}

Calculated $\chi^{2}$ value

Degree of freedom

Table value

Significant result
$=9.680$

$=3$

$=7.815$

$=$ Significant at $5 \%$ level

\section{Inference}

It is found from the above analysis that calculated chi-square value is greater than the table value at 3 degree of freedom. So, we conclude that, there is close significant relationship between the age and opinion about the advertisement.

Table 26: Educational Qualification and Opinion on Providing Information about Currency Value (Two-way Table)

\begin{tabular}{|c|l|c|c|c|}
\hline SI. No. & \multirow{2}{*}{$\begin{array}{c}\text { Educational } \\
\text { Qualification }\end{array}$} & \multicolumn{2}{|c|}{$\begin{array}{c}\text { Opinion on providing information } \\
\text { about currency value }\end{array}$} & \multirow{2}{*}{ Total } \\
\cline { 3 - 4 } & & The Hindu & The New Indian Express & \\
\hline 1 & School level & 6 & 4 & 10 \\
2 & UG level & 21 & 33 & 54 \\
3 & PG level & 14 & 13 & 27 \\
4 & Others & 8 & 1 & 9 \\
\hline & Total & 49 & 51 & 100 \\
\hline
\end{tabular}

Null Hypothesis $\left(H_{0}\right)$

- There is no significant relationship between educational qualification and opinion on providing information about currency value.

Alternative Hypothesis $\left(H_{1}\right)$ - There is close significant relationship between educational qualification and opinion on providing information about currency value. 


\section{Chi-square $\left(\chi^{2}\right)$ Calculation:}

$\begin{array}{ll}\text { Calculated } \chi^{2} \text { value } & =8.512 \\ \text { Degree of freedom } & =3 \\ \text { Table value } & =7.815 \\ \text { Significant result } & =\text { Significant at } 5 \% \text { level }\end{array}$

\section{Inference}

It is found from the above analysis that calculated chi-square value is greater than the table value at 3 degree of freedom. So, we conclude that, there is close significant relationship between the educational qualification and opinion on providing information about currency value.

\section{Summary of Findings, Suggestions and Conclusion}

\section{Findings}

- A majority (56\%) of the respondents belonging to the age group 20-30 years, read both "THE HINDU" and "THE NEW INDIAN EXPRESS" newspapers.

- It was found that the majority (69\%) of the respondents are female.

- It was found that the majority $(27 \%)$ of the respondents are students.

- The majority (54\%) of the respondents have completed their under graduation.

- The majority (58\%) of the respondents have chosen THE NEW INDIAN EXPRESS for simple usage of language.

- It was found that the majority (58\%) of the respondents have chosen THE HINDU for new approach of event.

- It was found that the majority (51\%) of the respondents have chosen THE HINDU for editorial matured essays. 
- It was found that the majority $56 \%$ of the respondents have chosen THE HINDU for welfare programmes of government.

- $56 \%$ of the respondents have chosen THE HINDU for correct employment news.

- It was found that the majority $55 \%$ of the respondents have chosen THE HINDU for accurate international news.

- $51 \%$ of the respondents have chosen THE NEW INDIAN EXPRESS for best educational news.

- The majority (56\%) of the respondents have chosen THE NEW INDIAN EXPRESS for up-to-date sports news.

- The majority (57\%) of the respondents have chosen THE HINDU for the mention of both merits and demerits of ruling government.

- $53 \%$ of the respondents have chosen THE NEW INDIAN EXPRESS for more youth development programs.

- The majority (58\%) of the respondents have chosen THE HINDU for best interviews with successful person.

- It was found that the majority $55 \%$ of the respondents have chosen THE HINDU for best business and economy news.

- The majority $(56 \%)$ of the respondents have chosen THE HINDU for maximum government contracts and tenders.

- $59 \%$ of the respondents have chosen THE HINDU for stock market news.

- The majority $(63 \%)$ of the respondents have chosen THE HINDU for advertisement news.

- It was found that the majority $51 \%$ of the respondents have chosen THE NEW INDIAN EXPRESS for best currency value news.

- The majority (54\%) of the respondents have chosen THE HINDU for best letters to the editors.

- $54 \%$ of the respondents have chosen THE HINDU for best photo clippings.

- The majority $(58 \%)$ of the respondents have chosen THE HINDU for suitable and useful supplements. 


\section{Chi-square Analysis Findings}

- There is close significant relationship between the age and opinion about the editorial essays.

- There is close significant relationship between the age and opinion about the advertisement.

- There is close significant relationship between the educational qualification and opinion on providing information about currency value.

\section{Suggestions}

\section{The Hindu}

- There should be simple usage of language.

- Educational news should be adequate.

- Correct political news have to be given.

- Employment news also should be concentrated.

- Youth development informations should be given importance.

- More concentration must be given on exposing the government development programmes to people.

- Useful medical news should be also included.

- Extra concentration must be given to local news.

- It must make people aware of our own environment.

- Business and economy information should be adequate.

\section{The New Indian Express}

- International affairs should be concentrated more.

- Information on stock market should be given importance.

- Business and economy sectors also have to be given extra concentration.

- Youth development oriented information should be given importance. 
- Photo clippings has to be added.

- Supplements for children's skill development can be given.

- Science and technology news should be more concentrated.

- Agriculture oriented news must be given.

- News related to rural development programmes should be added.

\section{Conclusion}

A study on readers preference of THE HINDU and THE NEW INDIAN EXPRESS newspaper has given us valuable information. This study helped to acquire the practical knowledge on doing a project. This study has given us great experience and made us understand the importance of newspaper. We could understand the satisfaction level of both THE HINDU and THE NEW INDIAN EXPRESS newspaper readers preference.

Thus it can be concluded that THE HINDU newspaper is the best when compared to THE NEW INDIAN EXPRESS newspaper due to various factors such as best photo clipping, editorial essays, good advertising, news approach of event, correct employment news etc.

\section{References}

1. Aaker David, A., Kumar, V. and George Day, S., "Marketing Research", John Wiley and Sons, New York, 2001.

2. Avadhani, V.A. "Global Business Finance", Himalaya Publishing House, Delhi, 2001.

3. Gupta, C.B., "Statistical methods", Himalaya Publishing House, Mumbai, 1997.

4. Rao, K.V. "Research-Methodology in Commerce and Marketing", Sterling Publishers Private Limited, New Delhi.

\section{Websites}

www.newspaperstudy.com

www.thehindu.com

www.newindpress.com 